\title{
Effects of Divalent Cations and of Phospholipase A Activity on Excretion of Cloacin DF13 and Lysis of Host Cells
}

\author{
By JOEN LUIRINK, ${ }^{1}$ CARINE VAN DER SANDE, 1 \\ JAN TOMMASSEN, ${ }^{3}$ ED VELTKAMP, ${ }^{2}$ FRITS K. DE GRAAF ${ }^{1}$ AND \\ BAUKE OUDEGA ${ }^{1 *}$ \\ Departments of ${ }^{1}$ Molecular Microbiology and ${ }^{2}$ Genetics, Biological Laboratory, Vrije Universiteit, \\ De Boelelaan 1087, $1081 \mathrm{HV}$ Amsterdam, The Netherlands \\ ${ }^{3}$ Institute of Molecular Biology, State University, Transitorium 3, Padualaan 8 , \\ 3584 CH Utrecht, The Netherlands
}

(Received 16 July 1985; revised 10 October 1985)

Induction of cloacin DF13 synthesis in Escherichia coli harbouring plasmid CloDF13 results in the release of cloacin DF13, inhibition of growth and ultimately in lysis of the host cells. Expression of the pCloDF13-encoded protein $\mathrm{H}$ is essential for both the release of cloacin DF13 and the lysis of the cells. The divalent cations $\mathrm{Mg}^{2+}$ and $\mathrm{Ca}^{2+}$ interfered with the mitomycin $\mathrm{C}$ induced, protein H-dependent lysis, but hardly affected the release of cloacin DF13. Essentially all of the bacteriocin was released from the cells before a detectable degradation of the peptidoglycan occurred, independent of the presence of mitomycin C. Experiments with phospholipase A mutants revealed that activation of detergent-resistant phospholipase A was essential for the export of cloacin DF13 across the outer membrane and the lysis of induced cells. Transport of cloacin DF13 across the cytoplasmic membrane was mainly dependent on protein H. A revised model for the excretion of cloacin DF13 is presented.

\section{INTRODUCTION}

Cells of Escherichia coli and Enterobacter cloacae harbouring the bacteriocinogenic plasmid CloDF13 synthesize cloacin, immunity protein and protein $\mathrm{H}$ (Van den Elzen et al., 1980; Hakkaart et al., 1981 a; Oudega et al., 1982). The genes encoding these proteins are co-ordinately transcribed from one common, mitomycin C-inducible promoter located proximal to the cloacin gene on pCloDF13 (Van den Elzen et al., 1980; Hakkaart et al., 1981b).

Cloacin and immunity protein form an equimolar complex, called cloacin DF13, which is excreted into the extracellular environment (Van Tiel-Menkveld et al., 1979; Oudega et al., 1982). Protein $\mathrm{H}$ is a polypeptide of 28 amino acid residues with a $M_{\mathrm{r}}$ of 2871 (Oudega et al., $1984 a$ ). The polypeptide is synthesized as a precursor with an amino-terminal signal sequence of 21 amino acid residues, and has been localized in both the cytoplasmic and outer membrane of $E$. coli minicells (Oudega et al., 1984b). The mature protein $\mathrm{H}$ is essential for the excretion of cloacin DF13, and for the lethal consequences and apparent lysis of cells induced with high concentrations of mitomycin C (Hakkaart et al., 1981 b; Van Tiel-Menkveld et al., 1981 ; Oudega et al., 1982, 1984a, b).

Genes functionally comparable to gene $\mathrm{H}$ of pCloDF 13 have been identified on the colicinogenic plasmids ColE1 (the kil gene, Sabik et al., 1983) and ColE2 (the celB gene, Pugsley \& Schwartz, 1983a,b). Also the plasmids ColE3, ColN and ColA seem to encode a protein Hlike product (Mock \& Schwartz, 1978; Jakes \& Model, 1979; Varenne et al., 1981; Pugsley, 1984; Jakes \& Zinder, 1984). The primary structures of the kil gene product, the celB gene

Abbreviation: DAP, $\varepsilon$-diaminopimelic acid. 
product, and the gene $\mathrm{H}$ product show extensive homology (Hakkaart et al., 1981 a; Stuitje et al., 1981; Pugsley \& Schwartz, 1984). The kil gene product and the celB gene product are also involved in the release of their respective colicins and the lysis or quasi-lysis of fully induced host cells (Mock \& Schwartz, 1978; Cavard et al., 1981 ; Pugsley \& Rosenbusch, 1981 ; Sabik et al., 1983; Jakes \& Zinder, 1984).

To obtain information on the mechanism by which protein $\mathrm{H}$ provokes (i) the release of cloacin DF13 and (ii) the lysis of host cells, and to study to what extent these events are related, we investigated the effect of protein $\mathrm{H}$ on the integrity of the cell envelope (i.e. degradation of peptidoglycan and phospholipids), as well as the effect of membrane-stabilizing divalent cations on the functioning of protein $\mathrm{H}$.

\section{METHODS}

Bacterial strains, plasmids and culture conditions. The bacterial strains and plasmids used in this study, and their relevant characteristics, are listed in Table 1. Plasmids were introduced into the appropriate strains by transformation according to the method of Dagert \& Ehrlich (1979). Plasmid DNA was isolated as described by Birnboim \& Doly (1979). To select for antibiotic resistance the following antibiotics and concentrations were used: ampicillin, $100 \mu \mathrm{g} \mathrm{ml}^{-1}$; kanamycin, $50 \mu \mathrm{g} \mathrm{ml}^{-1}$; and chloramphenicol, $30 \mu \mathrm{g} \mathrm{ml}^{-1}$. E. coli W7 was cultured in a minimal medium containing $2.0 \mathrm{~g} \mathrm{~K}_{2} \mathrm{HPO}_{4}, 2.6 \mathrm{~g} \mathrm{NaH}_{2} \mathrm{PO}_{4} .2 \mathrm{H}_{2} \mathrm{O}, 0.9 \mathrm{~g} \mathrm{NH}_{4} \mathrm{Cl}, 0.2 \mathrm{~g} \mathrm{MgSO}_{4} .7 \mathrm{H}_{2} \mathrm{O}, 5 \mathrm{mg}$ $\mathrm{FeCl}_{2}, 20 \mathrm{mg}$ lysine and $10 \mathrm{mg}$ DL- $\alpha, \varepsilon$-diaminopimelic acid (DAP, Sigma) per litre distilled water and $0.5 \%(\mathrm{w} / \mathrm{v})$ sodium lactate as a carbon source. The $\mathrm{pH}$ of the medium was 7.4. All other strains were cultured in Lab-Lemco broth (Oxoid) supplemented with $0.5 \%(\mathrm{w} / \mathrm{v}) \mathrm{NaCl}$ and $0.5 \%(\mathrm{w} / \mathrm{v})$ lactate. Cells harbouring a CloDF13 plasmid derivative with an insertion of transposon $\operatorname{Tn} 90 /$ or $\operatorname{Tn} 5$ were cultured in the presence of ampicillin or kanamycin, respectively. Cells carrying pPI232 were cultured in medium with chloramphenicol.

Induction, production, excretion and subcellular localization of cloacin DF13. Cloacinogenic cells were cultured and induced as described by Van Tiel-Menkveld et al. (1979, 1981). For sub-optimal induction of cloacin DF13 and protein $\mathrm{H}$, concentrations of 25 or $50 \mathrm{ng}$ mitomycin $\mathrm{C}(\mathrm{ml} \text { culture })^{-1}$ were used. Full induction was established with $250 \mathrm{ng}$ (ml culture) ${ }^{-1}$. The total production of cloacin DF13, the amount of cloacin DF13 excreted into the culture medium, and the amount of cloacin DF13 in various subcellular fractions were determined with Klebsiella edwardsii strain $\mathrm{S} 15$ as indicator strain for cloacin DF13 activity (in vivo killing assay), or immunologically with an enzyme-linked immunosorbent assay (ELISA). Both assays have been described previously (Van Tiel-Menkveld et al., 1979; Oudega et al., 1982). The isolation of subcellular fractions of $E$. coli, the assays of $\beta$-galactosidase and $\beta$-lactamase activity, and all other basic procedures were done as described previously (Van Tiel-Menkveld et al., 1979, 1981; Oudega et al., 1982).

Measurement of peptidoglycan degradation. The peptidoglycan of cells of E. coli W7 harbouring pJN73 was labelled with [ ${ }^{3} \mathrm{H}$ ]DAP by incubation of a minimal medium culture in the presence of $10 \mathrm{mM}-\left[{ }^{3} \mathrm{H}\right.$ ]DAP [specific activity $60 \mathrm{mCi} \mathrm{mmol}^{-1}\left(2.22 \mathrm{GBq} \mathrm{mmol}{ }^{-1}\right) \mathrm{CEA}$, France] for $18 \mathrm{~h}$ at $37^{\circ} \mathrm{C}$. Subsequently, the cells were collected by centrifugation $(12000 \mathrm{~g}, 10 \mathrm{~min})$, resuspended to an optical density at $660 \mathrm{~nm}$ of 0.1 in minimal medium containing lysine, DAP and $0.5 \%(\mathrm{w} / \mathrm{v})$ lactate, and incubated aerobically at $37^{\circ} \mathrm{C}$. One part of this culture was induced with the indicated concentrations of mitomycin $C$ at an optical density at $660 \mathrm{~nm}$ of $0 \cdot 2$. At intervals the loss of peptidoglycan labelled with $\left[{ }^{3} \mathrm{H}\right] \mathrm{DAP}$ was measured essentially as described by Leduc $e t$ al. $(1980,1982)$. Samples $(0.5 \mathrm{ml})$ were mixed with $0.5 \mathrm{ml}$ portions of $10 \%(\mathrm{w} / \mathrm{v}) \mathrm{TCA}$, and incubated for $1 \mathrm{~h}$ at $0{ }^{\circ} \mathrm{C}$. The suspensions were then filtered on membrane filters (pore size $0.2 \mu \mathrm{m}$; Millipore). The filters were washed three times with $5 \mathrm{ml} 5 \%(\mathrm{w} / \mathrm{v}) \mathrm{TCA}\left(0{ }^{\circ} \mathrm{C}\right)$ and the radioactivity retained on the filters was counted.

Labelling and analysis of lipids. Cells of the E. coli strains PC1602, F417 and S17, each without any plasmid, or with pJN73 or pVC3, were labelled overnight in Lab-Lemco broth supplemented with $\left[{ }^{14} \mathrm{C}\right]$ acetate $\left[10 \mu \mathrm{Ci} \mathrm{ml}^{-1}\right.$ $\left(370 \mathrm{kBq} \mathrm{ml}^{-1}\right) ; 58 \mathrm{mCi} \mathrm{mmol}^{-1}\left(2 \cdot 15 \mathrm{GBq} \mathrm{mmol}^{-1}\right)$; Amersham]. The cells were collected by centrifugation $(12000 \mathrm{~g}, 10 \mathrm{~min})$, and were washed and resuspended in fresh broth to an optical density at $660 \mathrm{~nm}$ of 0.05 . The cultures were further incubated at $37^{\circ} \mathrm{C}$ and at an optical density of 0.25 they were induced with mitomycin $\mathrm{C}$. Samples of $0.5 \mathrm{ml}$ were taken at various times and were analysed for lipids and free fatty acids. These were extracted from the samples by a modification of the method of Bligh \& Dyer as described by Duckworth $e t$ al. (1974). Lipids were separated by TLC on silica gel plates $(0.75 \mathrm{~mm}, 60 \mathrm{H}$, Merck) in chloroform/methanol/water/ acetic acid $(65: 25: 4: 1$, by vol.). Lipids were detected with iodine vapour by comparison with commercially available standards. Spots containing phosphatidylethanolamine, lysophosphatidylethanolamine and free fatty acids were scraped off into scintillation vials and counted. The radioactivity incorporated in these three compounds accounted for about $80-90 \%$ of that incorporated into extractable lipid and added to the TLC plate. 
Table 1. Bacterial strains and plasmids

Strain or plasmid designation

Klebsiella edwardsii subsp.
edwardsii S15

Escherichia coli W7

Escherichia coli K12
N3406

PC1602

F417

$\mathrm{S} 17$

Plasmids

pJN73

pVC3

pPI232
Relevant characteristics*

Susceptible to cloacin DF 13

Lys $^{-}$DAP-

$\mathrm{Thr}^{-} \mathrm{Leu}^{-} \mathrm{Thi}^{-} \mathrm{LacY}^{-}$TonA- ${ }^{-} \mathrm{SupE}^{-}$

F- MetE $^{-}$ThyA- Bio- EndA- $^{-}$Sup $^{-}$

Derivative of $\mathrm{PC1602}$; lacking detergentresistant phospholipase A activity

$\mathrm{F}^{-} \mathrm{Thr}^{-} \mathrm{Leu}^{-} \mathrm{Thi}^{-}$; lacking both detergentresistant and detergent-sensitive phospholipase A activity

pCloDF13:: Tn901, cop3;

$\mathrm{Clo}^{+} \mathrm{Imm}^{+} \mathrm{H}^{+} \mathrm{Amp}^{\mathrm{r}}$; insertion of $\mathrm{Tn} 90 \mathrm{I}$ at

$83 \%$ not affecting expression of the cloacin operon

pCloDF13: :Tn901, cop3;

$\mathrm{Clo}^{+} \mathrm{Imm}^{+} \mathrm{H}^{-} \mathrm{Amp}^{r} \mathrm{Km}^{\mathrm{r}}$; insertion of $\mathrm{Tn} 5$

in gene $\mathrm{H}$ not affecting expression of

cloacin and its immunity protein

Derivative of pACYC184 with a $11.0 \mathrm{~kb}$

DNA fragment of $E$. coli encoding

detergent-resistant phospholipase $\mathrm{A} ; \mathrm{Cm}^{r}$

\section{Reference}

De Graaf et al. (1969)

Leduc \& Van Heijenoort (1980);

Leduc et al. (1982)

Van Tiel-Menkveld et al. (1979);

Oudega et al. $(1982,1984 a, b)$

De Geus et al. (1983)

P. De Geus (personal

communication)

Doi et al. (1972); De Geus et al. (1983)

Van Tiel-Menkveld et al. (1979);

Oudega et al. (1982)

Oudega et al. (1982)

De Geus et al. (1983)

* $\mathrm{Clo}^{+}, \mathrm{Imm}^{+}$and $\mathrm{H}^{+}$indicate that cells harbouring $\mathrm{pJN} 73$ or $\mathrm{pVC} 3$ produce biologically active cloacin, immunity protein and protein $\mathrm{H}$, respectively; cop3 means that the plasmid originates from the CloDF 13 copy mutant CloDF13cop3.

\section{RESULTS}

\section{Effect of divalent cations on the functioning of protein $H$}

The effect of various concentrations of $\mathrm{Mg}^{2+}$-ions on the growth of mitomycin $\mathrm{C}$-induced cultures of $E$. coli N3406 harbouring pJN73 is shown in Fig. 1(a). In the absence of $\mathrm{Mg}^{2+}$ the optical density of the culture declined markedly within 2-3 h after induction. The presence of $\mathbf{M g}^{2+}$ ions protected the cells against this apparent lysis, the optimal concentration being $20 \mathrm{mM}$. At this concentration the increase in optical density of the culture was comparable to the growth of a non-induced culture (not shown). Higher concentrations of $\mathrm{Mg}^{2+}(50$ or $100 \mathrm{~mm}$ ) did not result in further protection or increase in culture optical density. When cultures were induced with low concentrations of mitomycin $\mathrm{C}$, the decline in optical density was less pronounced, and $20 \mathrm{mM}-\mathrm{Mg}^{2+}$ completely prevented the observed growth inhibition (data not shown).

$\mathrm{Ca}^{2+}$ ions had a similar protective effect to $\mathrm{Mg}^{2+}$ ions. The optimal concentration of $\mathrm{Ca}^{2+}$ was $10 \mathrm{~mm}$. The protective effect of $\mathrm{Mg}^{2+}$ and $\mathrm{Ca}^{2+}$ remained during prolonged incubation of the cells in the presence of high concentrations of mitomycin C. Moreover, addition of $\mathbf{M g}^{2+}$ to a 'lysing' culture protected the cells against further 'lysis' (Fig. 1a).

The effect of $\mathrm{Mg}^{2+}$ on the excretion of cloacin DF13 was also determined (Fig. 1 b). $\mathrm{Mg}^{2+}$ slightly reduced the excretion of bacteriocin produced after induction with a moderate $\left(25 \mathrm{ng} \mathrm{m}^{-1}\right)$ or high $\left(250 \mathrm{ng} \mathrm{ml}^{-1}\right)$ concentration of mitomycin $\mathrm{C}$, but the cells still excreted more than half of the bacteriocin they produced within $3 \mathrm{~h}$. Prolonged incubation of the cells resulted in a further excretion of bacteriocin (not shown). The total production of cloacin DF13 after sub-optimal and strong induction was about 17 and $28 \mu \mathrm{g} \mathrm{ml}^{-1}$, respectively. $\mathrm{Mg}^{2+}$ had no marked effect on the total production of cloacin DF13.

Similar results were obtained with cells harbouring the wild-type CloDF13 plasmid. The results indicated that divalent cations, as $\mathrm{Mg}^{2+}$ and $\mathrm{Ca}^{2+}$, reduce the mitomycin $\mathrm{C}$-induced lysis of cloacinogenic cells, but hardly affect the excretion of cloacin DF13. 


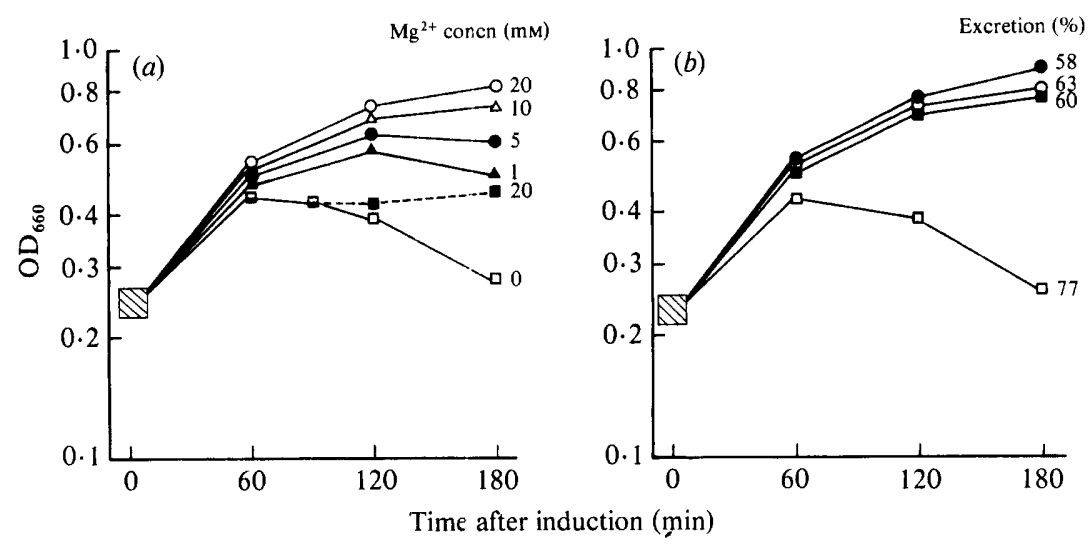

Fig. 1. Effect of $\mathrm{Mg}^{2+}$ ions on (a) the growth of $E$. coli $\mathrm{N} 3406$ harbouring pJN73, and (b) excretion of cloacin DF13. (a) - Optical density $\left(\mathrm{OD}_{660}\right)$ of cultures in broth supplemented with $0.5 \%(\mathrm{w} / \mathrm{v})$ lactate and the indicated concentration of $\mathrm{Mg}^{2+}\left(250 \mathrm{ng}\right.$ mitomycin $\mathrm{C} \mathrm{ml}^{-1}$ was added at $\left.t=0\right) ;---$, $\mathrm{OD}_{660}$ of an induced culture to which $20 \mathrm{mM}-\mathrm{Mg}^{2+}$ was added $90 \mathrm{~min}$ after induction was started. $(b)$ Cells were induced with $25 \mathrm{ng}(\mathrm{O}, 0)$, or with $250 \mathrm{ng}(\square, \square)$ mitomycin $\mathrm{C}$ (ml culture) $)^{-1}$, respectively. $\mathrm{Mg}^{2+}(20 \mathrm{~mm})$ was added at $t=0(\mathrm{O}, \square)$. The amount of cloacin DF13 in the cells and in the culture supernatant fractions was determined with the in vivo killing assay. The percentage of cloacin DF13 excreted is indicated to the right of the Figure.

\section{Degradation of peptidoglycan}

A close correlation exists between autolysis of $E$. coli cells and peptidoglycan degradation (Leduc \& Van Heijenoort, 1980; Leduc et al., 1982). We have investigated whether induction of cloacin DF13 and protein $\mathrm{H}$, and the subsequent decline in optical density of the culture, also resulted in a degradation of peptidoglycan. Cells of $E$. coli W7 harbouring pJN73 were labelled with $\left[{ }^{3} \mathrm{H}\right] \mathrm{DAP}$. After induction with two different concentrations of mitomycin $\mathrm{C}$, the optical density of the culture, the production and excretion of cloacin DF13, and the loss of peptidoglycan labelled with $\left[{ }^{3} \mathrm{H}\right] \mathrm{DAP}$ were determined simultaneously (Fig. 2). Induction with a high concentration of mitomycin $C\left(250 \mathrm{ng} \mathrm{ml}^{-1}\right)$ resulted in a decline in optical density of the culture after $3 \mathrm{~h}$, followed by release of $\left[{ }^{3} \mathrm{H}\right] \mathrm{DAP}$ after $6 \mathrm{~h}$. Under these conditions, excretion of cloacin DF13 started $2 \mathrm{~h}$ after induction and reached a maximum value of about $90 \%$ within 4-6 h. Essentially all of the bacteriocin was excreted before release of $\left[{ }^{3} \mathrm{H}\right] \mathrm{DAP}$ was observed. The presence of $\mathrm{Mg}^{2+}$ ions prevented the decrease of optical density and the release of $\left[{ }^{3} \mathrm{H}\right] \mathrm{DAP}$, but hardly affected the excretion of cloacin DF13 or its total production (about $50 \mu \mathrm{g} \mathrm{ml}^{-1}$ ).

Induction with a suboptimal amount of mitomycin $\mathrm{C}\left(25 \mathrm{ng} \mathrm{ml}^{-1}\right)$ resulted in a slight decline in optical density after $8 \mathrm{~h}$, but no release of $\left[{ }^{3} \mathrm{H}\right] \mathrm{DAP}$ was observed (data not shown). About $2 \mathrm{~h}$ after induction the cells started to excrete cloacin DF13 and about half of the bacteriocin was released by the cells within $4 \mathrm{~h}$. After that time the total amount of cloacin DF13 produced (about $16 \mu \mathrm{g} \mathrm{ml}^{-1}$ ) and the percentage of cloacin DF13 excreted remained constant. Comparable results were obtained in the presence of $20 \mathrm{mM}-\mathrm{Mg}^{2+}$, except that no decline in optical density was observed (data not shown). Induction of $E$. coli W7 harbouring pVC3 with a transposon insertion in gene $\mathrm{H}$ did not result in cloacin excretion, apparent lysis, or in a detectable degradation of labelled peptidoglycan. The results indicated that the initial decrease in the optical density of the culture and the excretion of cloacin DF13 after induction are not correlated with a detectable loss of peptidoglycan labelled with $\left[{ }^{3} \mathrm{H}\right] \mathrm{DAP}$.

Preliminary morphological investigations with the electron microscope revealed that induction of cloacinogenic cells resulted in local protuberances of the cell envelope during the time-period in which the initial decline in optical density of the culture and excretion of cloacin DF13 are observed. These protuberances were not observed when the cells were induced in the presence of $\mathrm{Mg}^{2+}$ or $\mathrm{Ca}^{2+}$. It is possible that the initial decline in optical density is caused by an altered scattering of light as a result of these protuberances. 


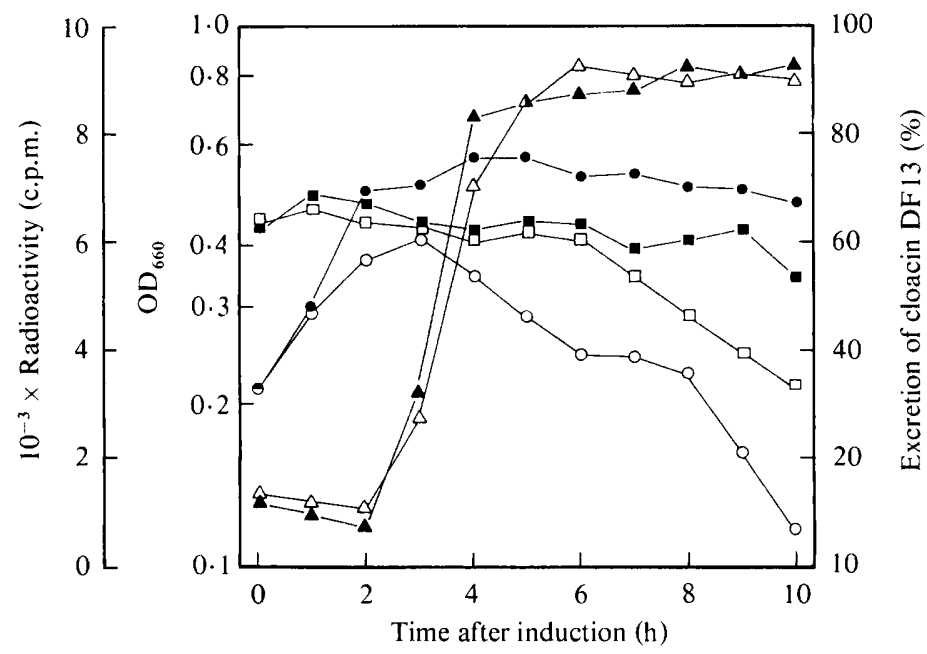

Fig. 2. Effect of mitomycin $\mathrm{C}$ and $\mathrm{Mg}^{2+}$ on the release of $\left[{ }^{3} \mathrm{H}\right] \mathrm{DAP}$, the excretion of cloacin DF13, and the $\mathrm{OD}_{660}$ of cultures of $E$. coli $\mathrm{W} 7$ harbouring $\mathrm{pJN} 73$ and precultured in the presence of $\left[{ }^{3} \mathrm{H}\right] \mathrm{DAP}$. The cells were incubated in minimal medium in the absence $(O, \triangle, \square)$, or presence $(O, \triangle, \square)$ of $20 \mathrm{mM}^{-}$ $\mathrm{Mg}^{2+}$; they were induced at $t=0$ with $250 \mathrm{ng}$ mitomycin $\mathrm{C} \mathrm{ml}-1.0,0, \mathrm{OD}_{660}$ of the cultures; $\triangle, \Delta$, excretion of cloacin DF13; $\square, \square$, acid-precipitable $\left[{ }^{3} \mathrm{H}\right] \mathrm{DAP}-$ labelled peptidoglycan. The amount of cloacin DF 13 in the cells and in the culture supernatant fractions was determined using ELISA. The total production of bacteriocin was about $50 \mu \mathrm{g} \mathrm{ml}^{-1}$, both in the presence and absence of $\mathrm{Mg}^{2+}$. Excretion is expressed as a percentage of the total production. The data on the release of $\left[{ }^{3} \mathrm{H}\right] \mathrm{DAP}$ are the mean values of several experiments, each done in duplicate (variance $5-10 \%$ ).

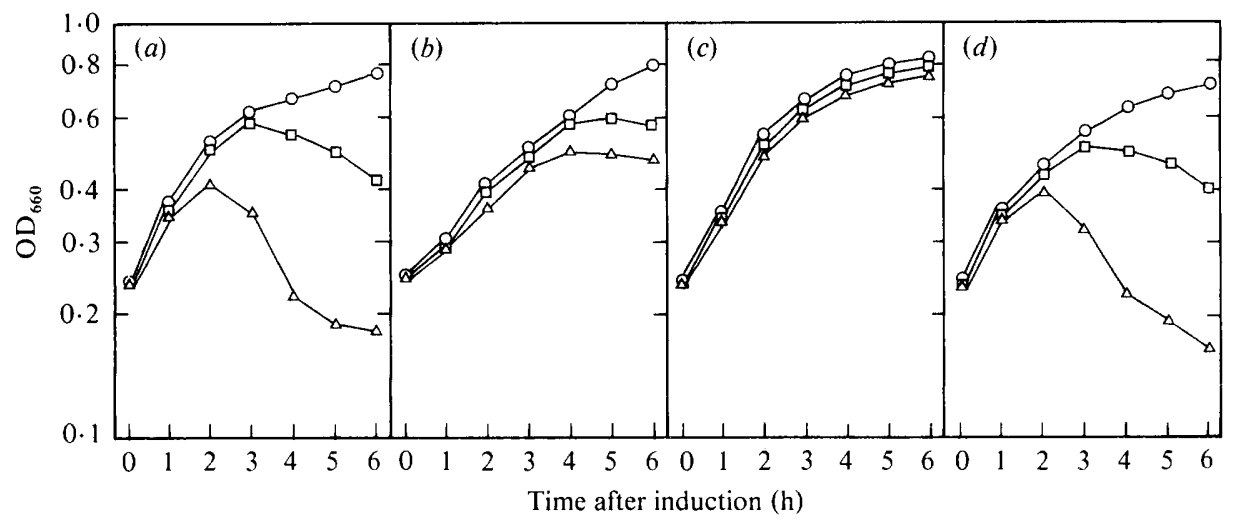

Fig. 3. Effect of mitomycin $C$ on the growth of various $E$. coli phospholipase A mutants. (a) Strain PC1602 with pJN73; (b) strain F417 with pJN73; (c) strain PC1602 with pVC3 (similar growth curves were obtained with strain $\mathrm{F} 417$ harbouring pVC3 and with strain $\mathrm{S} 17$ harbouring pVC3); (d) strain F417 harbouring pJN73 and pPI232. The cultures were grown without mitomycin $\mathrm{C}(\mathrm{O})$, or with $50 \mathrm{ng}$ $(\square)$ or $250 \mathrm{ng}(\triangle)$ mitomycin $\mathrm{C} \mathrm{ml}^{-1}$.

\section{Involvement of phospholipase $A$ activity}

Recently, Pugsley \& Schwartz (1984) showed that the release of colicin E2 might be due, at least in part, to the activation of the detergent-resistant phospholipase $\mathrm{A}$ by the pColE2-encoded lysis protein. To study whether phospholipase $A$ activities are also involved in the functioning of protein H, plasmid pJN73 was transferred to the E. coli strains PC1602, F417 and S17. Strain PC1602 has 'normal' phospholipase A activities and induction of cultures of this strain harbouring pJN73 resulted in 'normal' growth-inhibition and decrease in optical density of the culture (Fig. $3 a$ ). Strain F417 is defective in detergent-resistant phospholipase A activity in its 
outer membrane, whereas strain S17 lacks both detergent-sensitive phospholipase A in its cytoplasmic membrane and detergent-resistant phospholipase A activity in the outer membrane (Doi et al., 1972; Ohki et al., 1972; De Geus et al., 1983). These mutations strongly affected the mitomycin C-induced lysis of cells harbouring pJN73. Induction of cultures of strain F417 harbouring pJN73 resulted in less lysis (Fig. $3 b$ ). Induction of cultures of strain $\mathrm{S} 17$ harbouring pJN73 had an even smaller effect on cell growth (not shown). A comparable small effect of induction, as found with the latter strain, was observed with cultures of strains PC1602, F417 and S17 harbouring pVC3 (Fig. 3c) or harbouring no plasmid at all (not shown).

The absence of significant lysis in strain $\mathrm{F} 417$ harbouring pJN73 after induction could be completely complemented by the introduction of plasmid pPI232, which encodes detergentresistant phospholipase A activity (Fig. $3 d$ ). Similarly, the introduction of plasmid pPI232 into strain S17 harbouring pJN73 also resulted in a decline in optical density of the culture after strong induction (data not shown). Obviously, phospholipase A activity, especially the outer membrane-associated detergent-resistant phospholipase A activity, is required for the lysis of mitomycin $\mathrm{C}$-induced cloacinogenic cells.

Further evidence for the involvement of detergent-resistant phospholipase A activity came from experiments in which the degradation of phospholipids, especially of phosphatidylethanolamine, the major phospholipid in the outer membrane, was determined (Fig. 4). Induction of cultures of strain PC1602 harbouring pJN73 with a sub-optimal amount of mitomycin C resulted in a decrease in phosphatidylethanolamine and an increase in free fatty acids. These effects were also found in induced cultures of strain F417 harbouring both pJN73 and pPI232 but not in non-induced cultures; comparable results were obtained in the presence of divalent cations $\left(\mathrm{Ca}^{2+}, \mathrm{Mg}^{2+}\right)$ (data not shown). Control experiments revealed that induction of cultures of strain F417 or strain S17 harbouring either pJN73 or pVC3 did not result in a loss of labelled phosphatidylethanolamine or in an increase in labelled free fatty acid (data not shown). The experiments indicated that induction of cells harbouring a plasmid encoding protein $\mathrm{H}$ results in an activation of detergent-resistant phospholipase $A$ at an early stage, concomitant with or even prior to the induced decline in optical density of the culture (see also Fig. 3).

\section{Excretion and subcellular localization of cloacin DF 13 in phospholipase A mutants.}

Production and excretion of cloacin DF13 was determined in the phospholipase A mutants harbouring pJN73. Cultures were induced with a sub-optimal $\left(50 \mathrm{ng} \mathrm{ml}^{-1}\right)$ or high $\left(250 \mathrm{ng} \mathrm{ml}^{-1}\right.$ ) concentration of mitomycin $\mathrm{C}$ and the excretion of cloacin DF13 was determined at various times (Fig. 5). Under both induction conditions, the amount of bacteriocin excreted by the mutant strains was low as compared to the excretion by strain PC1602 harbouring pJN73. Cells of strain S17 excreted only a very low percentage of the bacteriocin during the induction period, independent of the mitomycin $\mathrm{C}$ concentration. Cells of strain F417 released more bacteriocin, especially after strong induction and longer periods. The total production of cloacin DF13 was about the same in all strains (Fig. 5), and comparable to the total production in E. coli N3406 harbouring pJN73 (Fig. $1 b$; Oudega et al., 1982). Cells harbouring pVC3 did not excrete significant amounts of cloacin DF13 (data not shown).

The subcellular localization of cloacin DF13 in the phospholipase A mutants was also determined (Table 2). In cells of strain F417 harbouring pJN73 more than half of the cellassociated bacteriocin was found in the periplasm, whereas only one-third could be detected in the spheroplast (cytoplasmic) fraction. In cells of strain S17 harbouring pJN73 about half of the bacteriocin was present in the spheroplasts and a smaller amount was detected in the periplasm. Only a small amount was excreted. The location of cloacin DF13 was also determined in cells of strains PC1602, F417 and S17 harbouring pVC3, and in cells of strains F417 and S17 harbouring both pJN73 and pPI232. In the absence of protein $\mathrm{H}$ practically all of the bacteriocin was found in the spheroplast (cytoplasmic) fraction, which is in agreement with previous experiments done with $E$. coli N3406 harbouring pVC3 (Oudega et al., 1982). Subcellular localization and excretion of cloacin DF13 by cells of strain F417 harbouring both pJN73 and pPI232 were comparable to those of strain PC1602 with pJN73. Cells of strain S17 harbouring both pJ N73 


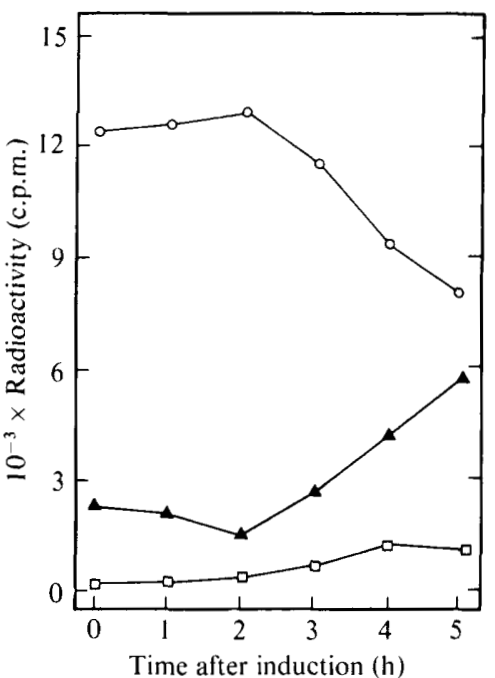

Fig. 4

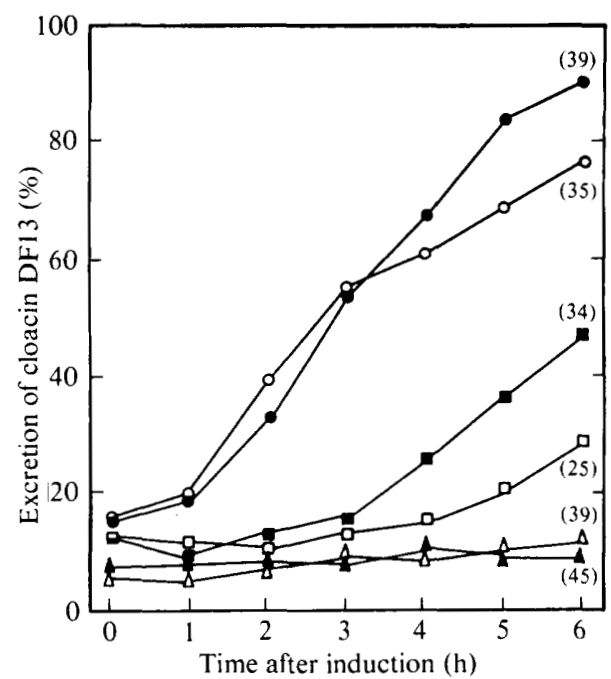

Fig. 5

Fig. 4. Degradation of phospholipid. Cells of strain PC1602 harbouring pJN73 were labelled with $\left[{ }^{14} \mathrm{C}\right]$ acetate and further cultured with $50 \mathrm{ng}$ mitomycin $\mathrm{C} \mathrm{ml}^{-1}$. At the indicated times samples were removed and analysed for lipids and free fatty acids, and the ${ }^{14} \mathrm{C}$-radioactivity present in phosphatidylethanolamine $(O)$, lysophosphatidylethanolamine $(\square)$ and in free fatty acids $(\boldsymbol{\Delta})$ was determined.

Fig. 5. Effect of mitomycin $\mathrm{C}$ on excretion of cloacin DF13 by E. coli phospholipase A mutants harbouring pJN73. Cultures of strain PC1602 harbouring pJN73 $(\mathrm{O}, \mathrm{O})$, strain $\mathrm{F} 417$ harbouring pJN73 $(\square, \square)$, and of strain $S 17$ harbouring pJN73 $(\triangle, \Delta)$ were induced with $50 \mathrm{ng}(O, \square, \triangle)$, or with $250 \mathrm{ng}(\mathbf{O}, \square, \Delta)$ mitomycin $\mathrm{C} \mathrm{ml}^{-1}$. The percentage of cloacin DFl3 excreted into the culture supernatant fractions was determined using ELISA. The total production of cloacin DF13 (the sum of the amounts in the cell and culture supernatant fractions) after $6 \mathrm{~h}$ is given in brackets $\left(\mu \mathrm{g} \mathrm{ml}^{-1}\right)$.

\section{Table 2. Localization of cloacin DFI3 in subcellular fractions of phospholipase A mutants}

Cells were induced by the addition of $25 \mathrm{ng}$ mitomycin $\mathrm{C}$ ( $\mathrm{ml}$ culture) ${ }^{-1}$; after $4 \mathrm{~h}$ supernatant fractions were collected. The cells were resuspended and periplasmic fractions and spheroplast fractions were prepared. The spheroplasts were not separated in a cytoplasmic and a membrane fraction, because no significant amounts of cloacin DF13 are present in the membranes (Van Tiel-Menkveld et al., 1979). The amount of cloacin DF13 in each fraction and the total production in the culture were determined immunologically (ELISA). The amount in each fraction was expressed as percentage of the total production. As controls, the percentages of $\beta$-galactosidase (cytoplasmic marker) and of $\beta$-lactamase (periplasmic marker) in the various fractions were determined and used for correction of the bacteriocin data due to experimental artefacts (corrections usually less than $6 \%$; see also Oudega et al. 1982). The bacteriocin data given are the mean values of several experiments, the variance being about $10 \%$.

Strain and plasmid(s)

Amount of cloacin DF13

$\mathrm{PC} 1602+$ pJN73

$\mathrm{PC} 1602+\mathrm{pVC} 3$

$\mathrm{F} 417+$ pJN73

$\mathrm{F} 417+\mathrm{pVC} 3$

$\mathrm{F} 417+$ pJN73 + pPI232

$\mathrm{S} 17+$ pJN73

$\mathrm{S} 17+\mathrm{pVC} 3$

$\mathrm{S} 17+$ pJN73 + pPI232

\begin{tabular}{|c|c|c|c|}
\hline \multicolumn{4}{|c|}{ Amount of cloacin DF13 } \\
\hline $\begin{array}{c}\text { Spheroplasts } \\
(\%)\end{array}$ & $\begin{array}{c}\text { Periplasm } \\
(\%)\end{array}$ & $\begin{array}{c}\text { Medium } \\
\text { fraction }(\%)\end{array}$ & $\begin{array}{l}\text { Total production } \\
\qquad\left(\mu \mathrm{g} \mathrm{ml}^{-1}\right)\end{array}$ \\
\hline
\end{tabular}

21

95

30

95

18

49

94

33
18

3

53

4

19

43

4

16
61

2

17

1

63

8

2
25

19

24

21

22

19

24

22 
and pPI232 excreted slightly less cloacin DF13. About half of the bacteriocin they produced was excreted, whereas cell-associated cloacin DF13 was located mostly in the spheroplasts. The total production of cloacin DF13 was about the same in all of the strains used.

\section{DISCUSSION}

The mechanism by which protein $\mathrm{H}$ molecules provoke the excretion of cloacin DF 13 and the lysis of fully induced cells is unknown. Cloacin and immunity protein are both synthesized without an amino-terminal signal sequence that could trigger their export (Oudega et al., 1982, $1984 a, b)$. In non-induced conditions, or after moderate induction with mitomycin $\mathrm{C}$, cloacin DF13 molecules first accumulate in the cytoplasm of producing cells, and are subsequently released into the culture medium during the late exponential phase of growth (Van TielMenkveld et al., 1979). This release occurs without a detectable decline in optical density of the culture, or apparent lysis, and appears to be rather specific since soluble proteins such as $\beta$ galactosidase and $\beta$-lactamase are not or hardly released (Van Tiel-Menkveld et al., 1979; Oudega et al., 1982). Under fully induced conditions, a strong reduction in culture optical density and a maximal release of cloacin DF13 are observed in the exponential growth phase (Van Tiel-Menkveld et al., 1979, 1981). Mature protein $\mathrm{H}$ molecules were found in both the cytoplasmic and outer membrane of E. coli minicells (Oudega et al., 1984b). It has been proposed that protein $\mathrm{H}$ might form some kind of pores in both membranes through which cloacin DF13 molecules traverse the cell envelope. A large number of these 'pores' might induce a decline in culture optical density and lysis.

The experiments described in this paper show that the two phenomena observed after induction of protein $\mathrm{H}$ synthesis, namely the decline in optical density of the culture and the excretion of cloacin DF13, are separate events. Divalent cations such as $\mathrm{Mg}^{2+}$ and $\mathrm{Ca}^{2+}$ strongly inhibited the mitomycin $\mathrm{C}$-induced, protein $\mathrm{H}$-dependent decline in culture optical density, possibly by stabilizing the outer membrane or preventing autolysis, but did not affect the excretion of cloacin DF13 significantly. Furthermore, the experiments with E. coli W7 demonstrated that essentially all of the cloacin DF13 was excreted before a release of $\left[{ }^{3} \mathrm{H}\right] \mathrm{DAP}$ from labelled peptidoglycan could be detected.

Recently, Pugsley \& Schwartz (1984) described the effects of $\mathrm{Mg}^{2+}$, Triton X-100, and of detergent-resistant phospholipase A activity in the outer membrane, on the growth of $E$. coli cells harbouring pColE2 and the release of colicin E2. They concluded that colicin E2 release is a consequence of a semi-specific leakage resulting from an alteration of the permeability properties of the cell envelope, and that this alteration might be due, at least in part, to the activation of the detergent-resistant phospholipase A by the pColE2-encoded 'lysis' protein. This activation might result in the formation of lysophosphatidylethanolamine, a membrane perturbant which could alter the permeability properties of the cell envelope. The assumption that such an activity is important for the release of bacteriocins is supported by the observation that the non-ionic detergent Triton X-100 enhances the release of colicin E2 in mitomycin Cinduced wild-type, as well as phospholipase A-deficient strains (Pugsley \& Schwartz, 1984). Our experiments with $E$. coli mutants defective in detergent-resistant and/or detergent-sensitive phospholipase A confirmed and extended these findings. Cells defective in detergent-resistant phospholipase A excreted only a low amount of cloacin DF13 into the culture medium, and more than half of the bacteriocin accumulated in the periplasm. Cells defective in both phospholipase $A$ activities excreted less cloacin DF13 into the culture medium, and about half of the bacteriocin was found in the cytoplasm. However, about $40 \%$ of the cloacin DF 13 produced was still found in the periplasm. Complementation of the mutation affecting detergent-resistant phospholipase A, by introduction of a plasmid encoding this enzyme, completely restored bacteriocin excretion and induced lysis in cells defective in detergent-resistant phospholipase $A$. Complementation of cells defective in both phospholipase A activities resulted in a significant release of cloacin DF13 and lysis of cells after strong induction, but complementation did not restore these effects completely. This indicates that detergent-sensitive phospholipase A activity might play a minor role in the translocation of cloacin DF13 molecules across the cell envelope. 
Based on the data presented in this paper we propose a modified model for the export of cloacin DF13 molecules. In the cytoplasmic membrane protein $\mathrm{H}$ molecules form specific pores through which molecules of cloacin DF13 can pass. Activation of detergent-sensitive phospholipase $\mathrm{A}$ in the cytoplasmic membrane possibly somewhat enhances the permeability of this membrane for cloacin DF13, but is not essential. Translocation of cloacin DF13 across the outer membrane and release into the culture medium is largely dependent on the activation of detergent-resistant phospholipase $\mathrm{A}$ in the outer membrane. Protein $\mathrm{H}$ molecules might directly activate phospholipase $\mathrm{A}$, or the activation could be the result of the interaction of protein $\mathbf{H}$ with the membrane. The combined activities of protein $\mathrm{H}$ and detergent-resistant phospholipase A might result in local permeability zones which rather selectively facilitate the release of cloacin DF13. Strong induction of cloacinogenic cells, resulting in large amounts of protein $\mathrm{H}$, causes a strong induction of both phospholipase $\mathrm{A}$ activities and the formation of numerous permeability zones. This process leads to severe damage to the membranes and ultimately to cell lysis, possibly by induction of the autolytic system of $E$. coli (Leduc et al., 1982). $\mathrm{Ca}^{2+}$ and $\mathrm{Mg}^{2+}$ ions interfere with this autolytic process and thus inhibit the decline in culture optical density and cell lysis.

We thank J. T. M. Wouters, U. Schwartz and P. De Geus for useful discussions, and P. Overduin for technical assistance. This investigation was supported in part by the Netherlands Organization for the advancement of Pure Research.

\section{REFERENCES}

Birnbiom, H. C. \& Doly, J. (1979). A rapid alkaline extraction procedure for screening recombinant plasmid DNA. Nucleic Acids Research 7, 1513-1523.

Cavard, D., Bernadac, A. \& Lazdunski, C. (1981). Exclusive localization of colicin A in cell cytoplasm of producing bacteria. European Journal of Biochemistry 119, 125-131.

DagerT, M. \& Ehrlich, S. D. (1979). Prolonged incubation in calcium chloride improves the competence of Escherichia coli cells. Gene 6, 23-28.

De Geus, P., Van Die, I., Bergmans, H., Tommassen, J. \& DE HAAS, G. (1983). Molecular cloning of pldA, the structural gene for outer membrane phospholipase of E. coli K12. Molecular and General Genetics 190, 150-155.

De GraAfF, F. K., Spanjaerdt-Speckman, E. A. \& Stouthamer, A. H. (1969). Mode of action of a bacteriocin produced by Enterobacter cloacae DF13. Antonie van Leeuwenhoek 35, 287-306.

DoI, O., OHKI, M. \& NoJima, S. (1972). Two kinds of phospholipase A and lysophospholipase in Escherichia coli. Biochimica et biophysica acta 260, 244-258.

Duckworth, D. H., Bevers, E. M., VerkLey, A. J., Op Den Kamp, J. A. F. \& Van Deenen, L. L. M. (1974). Action of phospholipase $A_{2}$ and phospholipase $\mathrm{C}$ on Escherichia coli. Archives of Biochemistry and Biophysics 165, 379-387.

HakkaART, M. J. J., VeltKamp, E. \& NiJkamp, H. J. J. (1981a). Protein $\mathrm{H}$ encoded by plasmid CloDF13 involved in lysis of the bacterial host. I. Location of the gene and identification and subcellular location of the gene $\mathrm{H}$ product. Molecular and General Genetics 183, 318-325.

HakkaArt, M. J. J., VeltKamp, E. \& NiJkamp, H. J. J. $(1981 b)$. Protein $\mathrm{H}$ encoded by plasmid CloDF13 involved in lysis of the bacterial host. II. Functions and regulation of synthesis of the gene $\mathrm{H}$ product. Molecular and General Genetics 183, 326-332.
JAKES, K. S. \& Model, P. (1979). Mechanism of export of colicin E1 and colicin E3. Journal of Bacteriology 138, 770-778.

JAKES, K. \& ZINDER, N. D. (1984). Plasmid ColE3 specifies a lysis protein. Journal of Bacteriology 157, 582-590.

Leduc, M. \& Van Heijenoort, J. (1980). Autolysis of Escherichia coli. Journal of Bacteriology 124, 52-59.

Leduc, M., Kasra, R. \& Van Heijenoort, J. (1982). Induction and control of the autolytic system of Escherichia coli. Journal of Bacteriology 152, 26-45.

Mock, M. \& SchwarTz, M. (1978). Mechanism of colicin E3 production in strains harboring wild-type or mutant plasmids. Journal of Bacteriology 136, 700 707.

OHKI, H., Osamu, D. \& NoJima, S. (1972). Mutant of Escherichia coli K-12 deficient for detergent-resistant phospholipase A. Journal of Bacteriology 110, 864869.

Oudega, B., Stegehuis, F., Van Tiel-Menkveld, G. J. \& De GraAF, F. K. (1982). Protein H encoded by plasmid CloDF13 is involved in excretion of cloacin DF13. Journal of Bacteriology 150, 1115-1121.

Oudega, B., Stegehuis, F. \& De Graaf, F. K. $(1984 a)$. Effect of glucose fermentation on the functioning of protein $\mathrm{H}$ in the excretion of cloacin DF13 by Escherichia coli. FEMS Microbiology Letters 21, 125-131.

Oudega, B., Ykema, A., Stegehuis, F. \& De Graaf, F. K. $(1984 b)$. Detection and subcellular localization of mature protein $\mathrm{H}$ involved in excretion of cloacin DF13. FEMS Microbiology Letters 22, 101-108.

Pugsley, A. P. (1984). Genetic analysis of ColN plasmid determinants for colicin production, release, and immunity. Journal of Bacteriology 158, 523-529.

Pugsley, A. P. \& Rosenbusch, J. P. (1981). Release of colicin E2 from Escherichia coli. Journal of Bacteri$\operatorname{olog} y 147,186-192$. 
Pugsley, A. P. \& Schwartz, M. (1983a). A genetic approach to the study of mitomycin-induced lysis of Escherichia coli K-12 strains which produce colicin E2. Molecular and General Genetics 190, 366-372.

Pugsley, A. P. \& SChwarTZ, M. (1983b). Expression of a gene in a 400-base-pair fragment of colicin plasmid ColE2-P9 is sufficient to cause host cell lysis. Journal of Bacteriology 156, 109-114.

Pugsley, A. P. \& Schwartz, M. (1984). Colicin E2 release: lysis, leakage or secretion? Possible role of phospholipase. EMBO Journal 3, 2393-2397.

SABIK, J. F., SUIT, J. L. \& LURIA, S. E. (1983). Cea-kil operon of the ColE1 plasmid. Journal of Bacteriology 153, 1479-1485.

Stuitje, A. R., Spelt, C. E., VeltKamp, E. \& NiJKAMP, H. J. J. (1981). Identification of mutations affecting the replication control of plasmid CloDF 13. Nature, London 290, 264-267.
Van den Elzen, P. J. M., Konings, R. N. H., VeltKamp, E. \& NiJKamp, H. J. J. (1980). Transcription of bacteriocinogenic plasmid CloDF13 in vivo and in vitro: structure of the cloacin-immunity operon. Journal of Bacteriology 144, 579-591.

Van Tiel-Menkveld, G. J., Rezee, A. \& De GraAF F. K. (1979). Production and excretion of cloacin DF13 by Escherichia coli harboring plasmid CloDF13. Journal of Bacteriology 140, 415-423.

Van Tiel-Menkveld, G. J., VeltKamp, E. \& De GrAAF, F. K. (1981). Mitomycin C-induced synthesis of cloacin DF13 and lethality in cloacinogenic Escherichia coli cells. Journal of Bacteriology 146, 4148.

Varenne, S., CaVard, D. \& Lazdunski, C. (1981). Biosynthesis and export of colicin A in Citrobacter freundii CA31. European Journal of Biochemistry 116, $615-620$. 